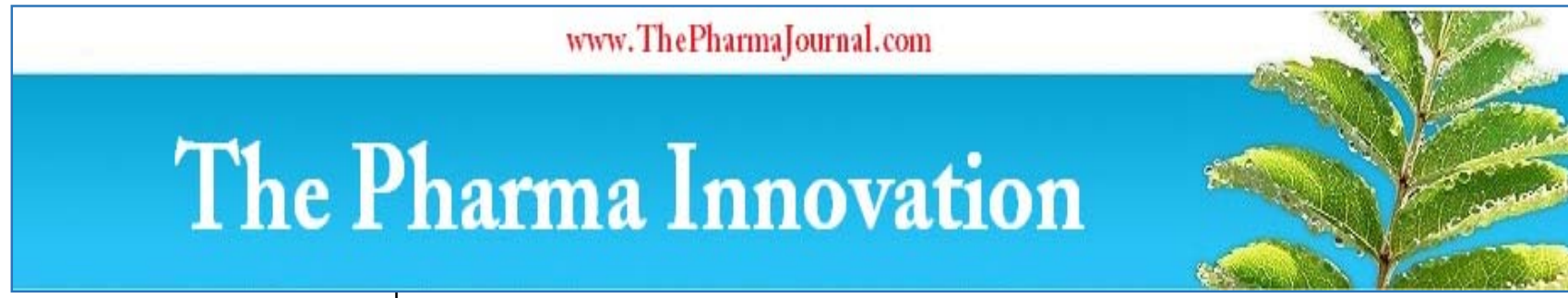

ISSN (E): 2277 - 7695 ISSN (P): 2349-8242 NAAS Rating: $\mathbf{5 . 0 3}$ TPI 2020; 9(2): 172-175 (C) 2020 TPI www.thepharmajournal.com Received: 16-12-2019 Accepted: 19-01-2020

Rajesh Kasrija

Assistant Professor,

Department of Veterinary and Animal Husbandry Extension Education Guru Angad Dev Veterinary and Animal Sciences University, Ludhiana, Punjab, India

Harish Kumar Verma Director, Department of Veterinary and Animal Husbandry Extension Education Guru Angad Dev Veterinary and Animal Sciences University, Ludhiana, Punjab, India

Rakesh Sharma

Director, Regional Research and Training Center, Talwara (Hoshiarpur, Punjab, India

Corresponding Author: Rajesh Kasrija

Assistant Professor, Department of Veterinary and Animal Husbandry Extension Education Guru Angad Dev Veterinary and Animal Sciences University, Ludhiana, Punjab, India

\section{Measurement of reproductive disorder remedial practice adoption (RDRPA) for curing infertility in dairy animals of Punjab}

\author{
Rajesh Kasrija, Harish Kumar Verma and Rakesh Sharma
}

DOI: https://doi.org/10.22271/tpi.2020.v9.i2d.4369

\section{Abstract}

The present study was conducted on 540 dairy farmers belonging to all the six different agro-climatic zones of Punjab by personal interview technique to assess Reproductive disorder remedial practice adoption (RDRPA) for curing infertility in dairy animals. The adoption rate was more for farmers running large dairy units followed by those running medium dairy units, then small dairy units. Unawareness and cost factor played a significant role in non-adoption. Adoption of remedial practices such as appropriate body weight, balanced diet feeding, comfortable housing, deworming, insemination by trained person significantly differ according to size of dairy units. There was significantly difference in mean RDRPA score of farmers running small, medium and large dairy units at $P<0.05$. The RDRPA level of farmers running small dairy units was low, while it was medium for those running medium and large dairy units and for overall dairy farmers of Punjab. The present study stresses formulation of farmer friendly, cost effective, easily understandable technologies for enhancing the adoption level.

Keywords: Adoption, Dairy, Farmer, Infertility, Punjab

\section{Introduction}

More than 70\% Indian rural households has livestock (Birthal and Jha 2005, Misra et al 2007), but still there is a considerable debate on India's ability to maintain milk supplies to its growing population in the coming decades. Despite rapid advances in the animal husbandry technologies and their role in improving livestock sector, productivity of this sector is still very low in India (Chander et al 2010). Although, Punjab is one of the leading states in dairying and milk production, producing 11.86 Million tonnes of milk, of the total milk production of country which is 176.3 Million Tonnes (National Dairy Development report, 2017-18, https://www.nddb.coop/information/stats/milkprodstate). But, in Punjab, the average milk yield/animal/day is $6.52 \mathrm{Kg}, 10.96 \mathrm{Kg}$, and $8.65 \mathrm{Kg}$ in nondescript cows, crossbred cows, and buffaloes respectively (Anonymous 2015). Anoestrus, repeat breeding, cystic ovarian degeneration, uterine and tubal disorders have been observed as the most common gynaecological problems in cattle and buffaloes (Agarwal et al 2005). The reproductive disorders such as repeat breeding and anoestrus lead to lesser calves and milk production, long service period and increase in intercalving interval, thereby causing economic losses. Concisely, lesser the reproductive losses in a dairy farm, more is the profitability of the venture. To curtail these losses, various remedial measures are available. But, there is poor diffusion and adoption of livestock technologies at field level (Melesse et al 2013), which may result in to infertility. The maintaining of infertile animal at dairy farm is an economic burden on dairy owners. So, a study was planned for assessing adoption of remedial measures used for curing infertility in dairy animals of Punjab.

\section{Materials and methods}

The present study was conducted in whole of Punjab state. On the basis of agro climatic conditions, Punjab has been divided into six different zones (Mahi and Kingra, 2013), namely Sub mountain undulating zone (Zone I), Undulating plain zone (Zone II), Central plain zone (Zone III), Western plain zone ( Zone IV), Western zone ( Zone V), and Flood plain zone (Zone VI). From each agro-climatic zone, the respondents were randomly selected and were categorized in to three different categories of 30 farmers each i.e., Group I (small dairy unit with 1-9 animals), Group II (medium dairy unit with 10-30 animals) and Group III (large dairy 
unit with more than 30animals). Thus, the total number of respondents was 90 in each agro-climatic zones. The overall number of farmers running small, medium and large dairy units were 180 each and total number of respondents belonging to different categories were 540 . The data were collected through a pre-structured and pre-tested interview schedule by personal interview technique. Each respondent was interviewed separately to avoid influence of other opinions. After consultation with subject matter experts and scrutinizing research literature, total 10 reproductive disorders remedial practices were enlisted. The farmers were also questioned to know about the adoption of these practices. The various factors affecting adoption of these practices were noted and categorized in to unawareness, unavailability, cost factor and complexity of technology. The farmer adopting a particular practice was given score one while farmer not adopting technology was graded zero for that particular practice. The Reproductive disorder remedial practice adoption (RDRPA) score and level were calculated. Farmers having RDRPA score up to $3, \geq 3-6$ and more $>6$ were categorized in to low, medium and high RDRPA level. For analysis, simple tabular techniques and appropriate statistical methods were employed by using SPSS version 22.0.

\section{Results and discussion}

Table 1 depicts RDRPA status among dairy farmers of Punjab. The adoption rate about remedial measures was more for farmers running large dairy units followed by those running medium dairy units, then small dairy units. In an earlier study, it was also reported that there was significant difference $(p<0.05)$ in RDRPA score of small and large dairy farmers in Undulating plain zone of Punjab (Kasrija et al 2016). Overall, analysis of Punjab indicated that unawareness and cost factor played a significant role in non-adoption of remedial measures. Unavailability and complexity of technology were also having some role in non-adoption. Sah and Chand (1999) stated that the lowest adoption in breeding practices may be due to complicated nature of some of the breeding practices.

Unawareness level was reported more in farmers running small dairy units. Raut et al (1989) also reported that there has been a wide gap between the extent of knowledge of improved dairying practices by the farmers and their actual adoption. Cost factor was also main hindrance for adoption. Ganai et al (2008) also reported that although the feed was available in the market, $74.80 \%$ of the farmers could not afford to purchase the feeds due to the high costs. It can be concluded from forgoing that unawareness and cost factor are major hindrance for adoption of remedial measure for curtailing infertility. So, the need of hour is to formulate costeffective and easily understandable technologies so as to enhance the adoption level.

Table 2 describes Chi square values of Logistic regression of RDRPA for different dairy units. On multinomial logistic regression analysis it was found that remedial measures bearing (*) significantly differ according to size of dairy units in different zones. Overall analysis of Punjab indicated that adoption of remedial practices such as appropriate body weight, balanced diet feeding, comfortable housing, deworming, insemination by trained person significantly differ according to size of dairy units.

Table 3 and Figure 1 describe RADRPA score and level among dairy farmers of different zones of Punjab. There was significant difference in mean RDRPA score of Zone I and III at $\mathrm{P}<0.05$. The RDRPA level was low for zone I, while it was medium for rest of zones and for overall Punjab. It suggests that adoption score of remedial practice used for curing infertility varies from zone to zone. So, a single policy for whole of the state should not be formulated. Singh and Gill (1993) also reported that the adoption of dairy technologies varies from region to region depending on various factors.

Table 1: RDRPA status among dairy farmers of Punjab

\begin{tabular}{|c|c|c|c|c|c|c|c|c|c|c|c|c|}
\hline \multirow[b]{2}{*}{$\begin{array}{c}\text { Dairy } \\
\text { unit }\end{array}$} & \multirow{2}{*}{\multicolumn{2}{|c|}{ Adoption status }} & \multicolumn{10}{|c|}{ Remedial measure practice } \\
\hline & & & $\begin{array}{l}\text { Appropriate } \\
\text { body weight }\end{array}$ & \begin{tabular}{|c|}
$\begin{array}{c}\text { Feeding } \\
\text { ration to } \\
\text { heifer }\end{array}$ \\
\end{tabular} & \begin{tabular}{|c|} 
Balanced \\
diet \\
feeding
\end{tabular} & \begin{tabular}{|l|}
$\begin{array}{l}\text { Mineral } \\
\text { mixture } \\
\text { feeding }\end{array}$ \\
\end{tabular} & $\begin{array}{c}\text { Comfortable } \\
\text { housing }\end{array}$ & Deworming & \begin{tabular}{|c|} 
Insemination \\
by trained \\
person
\end{tabular} & $\begin{array}{c}\text { Right time } \\
\text { of } \\
\text { insemination }\end{array}$ & $\begin{array}{l}\text { Hormonal } \\
\text { treatment }\end{array}$ & $\begin{array}{c}\text { Intrauterine } \\
\text { treatment }\end{array}$ \\
\hline \multirow{5}{*}{$\begin{array}{c}\text { Small } \\
(\mathrm{n}=180)\end{array}$} & Adopted & & $9(5)$ & $29(16.11)$ & $39(21.67)$ & $46(25.56)$ & $29(16.11)$ & $74(41.11)$ & $127(70.56)$ & $57(31.67)$ & $14(7.78)$ & $43(23.89)$ \\
\hline & \multirow{4}{*}{$\begin{array}{c}\text { Non } \\
\text { adopted }\end{array}$} & Unawareness & $113(62.78)$ & $78(43.33)$ & $73(40.56)$ & $91(50.55)$ & $93(51.67)$ & $92(51.11)$ & $53(29.44)$ & $111(61.67)$ & $61(33.89)$ & $83(46.11)$ \\
\hline & & Cost factor & $58(32.22)$ & $72(40.0)$ & $59(32.78)$ & $42(23.33)$ & $51(28.33)$ & $14(7.78)$ & $0(0)$ & $0(0)$ & $48(26.67)$ & $26(14.44)$ \\
\hline & & Unavailability & $0(0)$ & $1(0.56)$ & $0(0)$ & $1(0.56)$ & $0(0)$ & $0(0)$ & $0(0)$ & $10(5.55)$ & & $10(5.55)$ \\
\hline & & $\begin{array}{c}\text { Complexity of } \\
\text { technology }\end{array}$ & $0(0)$ & $0(0)$ & $9(5)$ & $0(0)$ & $7(3.89)$ & $0(0)$ & $0(0)$ & $2(1.11)$ & $38(21.11)$ & $18(10.0)$ \\
\hline \multirow{5}{*}{$\begin{array}{l}\text { Medium } \\
(\mathrm{n}=180)\end{array}$} & Adopted & & $28(15.56)$ & $43(23.89)$ & $59(32.78)$ & $62(34.44)$ & $44(24.44)$ & $96(53.33)$ & $116(64.44)$ & $62(34.44)$ & $24(13.33)$ & $63(35.0)$ \\
\hline & \multirow{4}{*}{$\begin{array}{c}\text { Non } \\
\text { adopted }\end{array}$} & Unau & & $80(44.44)$ & $63(35.0)$ & $72(40.0)$ & 85 & $69(38.33)$ & $64(35.55)$ & & $0.0)$ & 46.11) \\
\hline & & & $57(31.67)$ & 57 (31.67) & $49(27.22)$ & $44(24.44)$ & $41(22.78)$ & $15(8.33)$ & & & $2.22)$ & \\
\hline & & \begin{tabular}{|l} 
Unavai \\
\end{tabular} & $0(0)$ & $0(0)$ & $0(0)$ & $2(1.11)$ & 0 & $0(0)$ & $0(0)$ & $10(5.55)$ & $16(8.89)$ & \\
\hline & & $\begin{array}{r}\text { Comp } \\
\text { tech }\end{array}$ & $0(0)$ & $0(0)$ & $9(5)$ & $0(0)$ & $10(5.55)$ & $0(0)$ & $0(0)$ & $0(0)$ & $46(25.55)$ & $10(5.55)$ \\
\hline \multirow{5}{*}{$\begin{array}{c}\text { Large } \\
(\mathrm{n}=180)\end{array}$} & Adopted & & $57(31.67)$ & $59(32.78)$ & $108(60.0)$ & $74(41.11)$ & $75(41.67)$ & $120(66.67)$ & $111(61.67)$ & $83(46.11)$ & $34(18.89)$ & $80(44.44)$ \\
\hline & \multirow{4}{*}{$\begin{array}{c}\text { Non } \\
\text { adopted }\end{array}$} & Una & & $73(40.56)$ & $52(28.89)$ & $68(37$ & & 54 & $68(3$ & 87( & & \\
\hline & & & $65(36.11)$ & $48(26.67)$ & $14(7.78)$ & $36(20.0)$ & 19( & $6(0.03)$ & 0( & & $9.44)$ & $15(8.33)$ \\
\hline & & \begin{tabular}{|l} 
Unavailability \\
\end{tabular} & $0(0)$ & $0(0)$ & $0(0)$ & $2(1.11)$ & $0(0)$ & $0(0)$ & $1(0.56)$ & $8(4.44)$ & $14(7.78)$ & $0(0)$ \\
\hline & & $\begin{array}{c}\text { Complexity of } \\
\text { technology }\end{array}$ & $1(0.56)$ & $0(0)$ & $6(3.33)$ & $0(0)$ & $12(6.67)$ & $0(0)$ & $0(0)$ & $2(1.11)$ & $42(23.33)$ & $10(5.55)$ \\
\hline \multirow{5}{*}{$\begin{array}{l}\text { Over all } \\
(\mathrm{n}=540)\end{array}$} & Adopted & & $94(17.41)$ & $\begin{array}{c}131 \\
(24.26)\end{array}$ & $\begin{array}{c}206 \\
(38.15)\end{array}$ & $\begin{array}{c}182 \\
(33.70)\end{array}$ & $148(27.41)$ & $290(53.70)$ & $354(65.56)$ & $202(37.41)$ & $72(13.33)$ & $186(34.44)$ \\
\hline & \multirow{4}{*}{$\begin{array}{c}\text { Non } \\
\text { adopted }\end{array}$} & Unawareness & $265(49.07)$ & $\begin{array}{c}231 \\
(42.78) \\
\end{array}$ & $\begin{array}{c}188 \\
(34.81) \\
\end{array}$ & $\begin{array}{c}231 \\
(42.78) \\
\end{array}$ & $252(46.67)$ & $215(39.81)$ & $185(34.26)$ & $306(56.67)$ & $170(31.48)$ & $241(44.63)$ \\
\hline & & Cost factor & $180(40)$ & $\begin{array}{c}177 \\
(32.78) \\
\end{array}$ & $\begin{array}{c}122 \\
(25.59) \\
\end{array}$ & $\begin{array}{c}122 \\
(25.59) \\
\end{array}$ & $111(20.55)$ & $35(6.48)$ & $0(0)$ & $0(0)$ & $123(22.78)$ & $57(10.56)$ \\
\hline & & Unavailability & $0(0)$ & $1(0.19)$ & $0(0)$ & $5(0.009)$ & $0(0)$ & $0(0)$ & $1(0.19)$ & 28 (5.19) & $49(9.07)$ & $18(3.33)$ \\
\hline & & $\begin{array}{c}\text { Complexity of } \\
\text { technology }\end{array}$ & $1(0.19)$ & $0(0)$ & $24(4.44)$ & $0(0)$ & $29(5.37)$ & $0(0)$ & $0(0)$ & $4(0.74)$ & $126(23.33)$ & $38(7.04)$ \\
\hline
\end{tabular}

Figure in parenthesis indicate percentage 
Table 2: Chi square values of Logistic regression of RDRPA for different dairy units

\begin{tabular}{|c|c|c|c|c|c|c|c|c|}
\hline \multirow{2}{*}{ Sr. No. } & & \multicolumn{6}{|c|}{ Agroclimatic zones } & \multirow{2}{*}{ Overal } \\
\hline & Remedial practice & Sub mountain undulating & Undulating plair & Central plain & Western plain & Western & Flood plain & \\
\hline 1 & Appropriate body weight & 4.637 & 5.419 & 2.088 & $23.432 *$ & $9.132 *$ & $10.421 *$ & $38.765^{*}$ \\
\hline 2 & Feeding ration to heifer & 3.665 & 8.087 & $0.034 *$ & 0.221 & 0.318 & 2.939 & 4.574 \\
\hline 3 & Balanced diet feeding & $9.143^{*}$ & 19.095 & $1.969^{*}$ & 2.565 & $9.062 *$ & $11.589^{*}$ & $34.137^{*}$ \\
\hline 4 & Mineral mixture feeding & 0.475 & 1.768 & 0.068 & 0.171 & 0.116 & 5.014 & 0.826 \\
\hline 5 & Comfortable housing & 2.263 & 5.211 & 2.968 & 9.729* & 0.801 & 1.871 & $12.065^{*}$ \\
\hline 6 & Deworming & 1.566 & 4.304 & 0.919 & $6.654^{*}$ & 2.142 & 3.473 & $11.972^{*}$ \\
\hline 7 & Insemination by trained person & 1.035 & 2.501 & $10.895 *$ & $26.444 *$ & 1.103 & 5.892 & $20.919^{*}$ \\
\hline 8 & Right time of insemination & 1.548 & 0.625 & 0.046 & $19.592^{*}$ & 1.659 & 0.354 & 1.948 \\
\hline 9 & Hormonal treatment & 1.864 & 0.566 & 0.336 & 2.005 & 0.911 & 0.181 & 0.131 \\
\hline 10 & Intrauterine treatment & 0.840 & 1.201 & 2.804 & 5.941 & 1.217 & 0.070 & 2.853 \\
\hline
\end{tabular}

(*) Practice significantly differ according to size of dairy unit

Table 3: RADRPA score and level among dairy farmers of different zones of Punjab

\begin{tabular}{|c|c|c|c|}
\hline $\begin{array}{c}\text { Zone } \\
\text { number }\end{array}$ & Agroclimatic zone & $\begin{array}{c}\text { RADRPA score } \\
(\text { Rean } \pm \text { S.E) }\end{array}$ & $\begin{array}{c}\text { RARPA } \\
\text { level }\end{array}$ \\
\hline I & $\begin{array}{c}\text { Sub mountain undulating } \\
(\mathrm{n}=90)\end{array}$ & $2.98^{\mathrm{a}} \pm 0.21$ & Low \\
\hline II & Undulating plain $(\mathrm{n}=90)$ & $3.33^{\mathrm{ab}} \pm 0.19$ & Medium \\
\hline III & Central plain $(\mathrm{n}=90)$ & $4.20^{\mathrm{c}} \pm 0.26$ & Medium \\
\hline IV & Western plain $(\mathrm{n}=90)$ & $3.56^{\mathrm{bc}} \pm 0.22$ & Medium \\
\hline V & Western region $(\mathrm{n}=90)$ & $3.42^{\mathrm{ab}} \pm 0.26$ & Medium \\
\hline VI & Flood plain $(\mathrm{n}=90)$ & $3.26^{\mathrm{ab}} \pm 0.22$ & Medium \\
\hline & Over all $(\mathrm{n}=540)$ & $3.46 \pm 0.09$ & Medium \\
\hline
\end{tabular}

Values with different superscript differ significantly at $P<0.05$

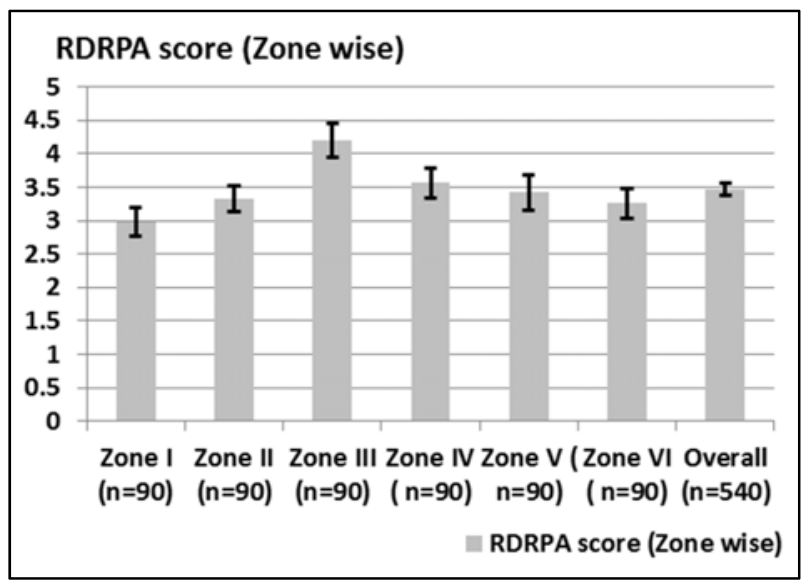

Fig 1: RDRPA score in different zones of Punjab

Table 4 and Figure 2 describe RADRPA score and level among dairy farmers of Punjab. There was significantly difference in mean RDRPA score of farmers running small, medium and large dairy units at $P<0.05$. The RDRPA level of farmers running small dairy units was low, while it was medium for those running medium and large dairy units and for overall dairy farmers of Punjab.

Table 4: RADRPA score and level among dairy farmers of Punjab

\begin{tabular}{|c|c|c|}
\hline Dairy unit & RADRPA score (Mean \pm S.E) & RADRPA level \\
\hline Small $(\mathrm{n}=180)$ & $2.59^{\mathrm{a}} \pm 0.15$ & Low \\
\hline Medium $(\mathrm{n}=180)$ & $3.29^{\mathrm{b}} \pm 0.15$ & Medium \\
\hline Large $(\mathrm{n}=180)$ & $4.49^{\mathrm{c}} \pm 0.16$ & Medium \\
\hline Over all $(\mathrm{n}=540)$ & $3.46 \pm 0.09$ & Medium \\
\hline
\end{tabular}

Values with different superscript differ significantly at $P<0.05$

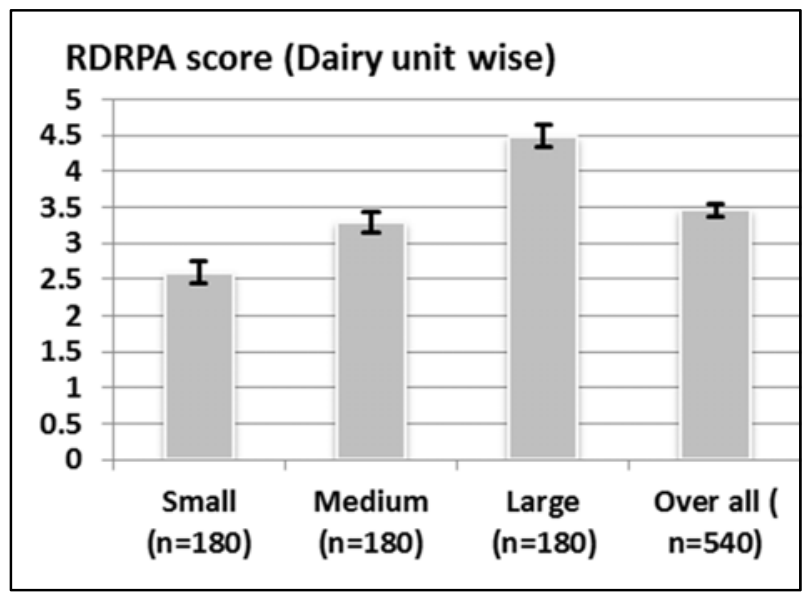

Fig 2

Table 5 represents correlation coefficient ' $r$ ' value of RDRPA with demographic and communicational profile in Punjab. The RDRPA score was significantly correlated with education, land holding, training, mass media exposure and extension contacts at 0.01 level (2-tailed). This means that farmers having more education level had more RDRPA i.e. adopted more remedial measures for reproductive disorders. Farmers having more land holding had more approach to resources for more

RDRPA. More the mass media exposure and extension contacts, more the RDRPA level. This indicates that extension agencies can play a vital role in knowledge dissemination and adoption of a technology.

Also, RDRPA increases by increase in training, mass media exposure, social participation and extension contacts. Sarkar (1981) also reported that adoption level of dairy farmers was highly significantly associated with their family education status, dairy farm income, herd size, average lactation yield and risk preferences. The adoption level was significantly related with land holding and social participation. However, Sheron and Kumar (1988) reported that extension contacts were not found to have significant relationship with feeding and management but it has negative and highly significant correlation with breeding, healthcare and overall adoption. But, Singh (1991) reported a positive and significant correlation of land holding, family education status, herd size, milk production and mass media exposure with adoption of improved dairy husbandry practices. 
Table 5: Correlation coefficient ' $r$ ' value of RDRPA with demographic and communicational profile in Punjab

\begin{tabular}{|c|c|c|c|c|c|c|c|c|c|}
\hline $\begin{array}{c}\text { Pearson's correlation } \\
\text { coefficient ' } r \text { ' }\end{array}$ & $\begin{array}{c}\text { RDRPA } \\
\text { score }\end{array}$ & Age & Education & $\begin{array}{c}\text { Family } \\
\text { size }\end{array}$ & $\begin{array}{c}\text { Land } \\
\text { holding }\end{array}$ & Training & $\begin{array}{c}\text { Mass media } \\
\text { exposure }\end{array}$ & $\begin{array}{c}\text { Social } \\
\text { participation }\end{array}$ & $\begin{array}{c}\text { Extension } \\
\text { contact }\end{array}$ \\
\hline RDRPA score & 1 & 0.01 & $0.594^{* *}$ & 0.017 & $0.420^{* * *}$ & $0.558^{* *}$ & $0.604^{* *}$ & $0.623^{* *}$ & $0.608^{* *}$ \\
\hline Age & 0.01 & 1 & 0.044 & $0.233^{* *}$ & -0.025 & -0.043 & 0.051 & 0.029 & 0.074 \\
\hline Education & $0.594^{* *}$ & 0.044 & 1 & 0.073 & $0.437^{* *}$ & $0.484^{* *}$ & $0.664^{* *}$ & $0.690^{* *}$ & $0.697^{* *}$ \\
\hline Family size & 0.017 & $0.233^{* *}$ & 0.073 & 1 & -0.032 & 0.005 & 0.069 & 0.066 & 0.063 \\
\hline Land holding & $0.420^{* *}$ & -0.025 & $0.437^{* *}$ & -0.032 & 1 & $0.405^{* *}$ & $0.509^{* *}$ & $0.506^{* *}$ & $0.529^{* *}$ \\
\hline Training & $0.558^{* *}$ & -0.043 & $0.484^{* *}$ & 0.005 & $0.405^{* *}$ & 1 & $0.506^{* *}$ & $0.496^{* *}$ & $0.505^{* *}$ \\
\hline Mass media exposure & $0.604^{* *}$ & 0.051 & $0.664^{* *}$ & 0.069 & $0.509^{* *}$ & $0.506^{* *}$ & 1 & $0.921^{* *}$ & $0.907^{* *}$ \\
\hline Social participation & $0.623^{* *}$ & 0.029 & $0.690^{* *}$ & 0.066 & $0.506^{* *}$ & $0.496^{* *}$ & $0.921^{* *}$ & 1 & $0.909^{* *}$ \\
\hline Extension contact & $0.608^{* *}$ & 0.074 & $0.697^{* *}$ & 0.063 & $0.529^{* *}$ & $0.505^{* *}$ & $0.907^{* *}$ & $0.909^{* *}$ & 1 \\
\hline
\end{tabular}

(**) Correlation is significant at the 0.01 level (2-tailed).

\section{References}

1. Kasrija R, Verma HK, Gandotra VK Assessment of Reproductive Disorder Remedial Practice (RDRPA) adoption by dairy farmers in Undulating plain region of Punjab. Indian Journal of Animal Reproduction. 2016; 37(1):43-44.

2. Birthal PS, Jha AK. Economic losses due to various constraints in dairy production in India. Indian Journal of Animal Science. 2005; 75:1470-75.

3. Misra AK, Rama Rao CA, Subrahmanyam KV, Vijay Sankar Babu M, Shivarudrappa B, Ramakrishna YS. Strategies for livestock development in rainfed agroecosystem of India. Livestock Research for Rural Development, 2007. 19: Article \#83. (Retrieved from http://www.lrrd.org/lrrd19/6/misr19083.htm)

4. Chander M, Dutt T, Ravikumar R, Subrahmanyeswari B. Livestock technology transfer service in India: A review. The Indian Journal of Animal Science. 2010; 80:1115-25.

5. Anonymous. Focus paper on Animal husbandry sector Vision 2017, Department of Animal husbandry, Punjab, 2015.

6. Agarwal SK, Singh SK, Rajkumar R. Reproductive disorders and their management in cattle and buffalo: A review. Indian Journal of Animal Science. 2005; 75(7):858-73.

7. Melesse K, Jemal J, Melesse A. Factors affecting the level of adoption of dairy technologies in Ada'a and Lume Districts, East Shoa Ethiopia. Agricultural Science Research Journals. 2013; 3(8):237-43.

8. Mahi, Kingra. Fundamentals of Agrometerology. Kalyani Publishers, Ludhiana, 2013, 236-40.

9. Sah AK, Chand R. Adoption of improved dairy practices in Bihar. Indian J Extn Edu. 1999; 35:234-37.

10. Raut DR, Nayak HS, Kulkarni MB. A study of knowledge and adoption of improved dairy practices by the dairy farmers of Ahmednagar district. Livestock Advisor. 1989; 14:34-39.

11. Ganai AM, Mattoo PA, Ahmad HA. Knowledge level and constraints faced by livestock owners in Kashmir valley. Indian Veterinary Journal. 2008; 85(3):337-38.

12. Singh A, Gill S. Review of adoption research studies in Indian Journal of Extension Education from 1980-1987. Livestock Advisor. 1993; 12:34-39.

13. Sarkar AK. A study of communication patterns and factors affecting adoption of technology in West Bengal, $\mathrm{PhD}$. Dissertation, National Dairy Research Institute, Karnal, 1981.

14. Sheron UK, Kumar R. Correlates of adoption of dairy innovations of IRDP beneficiaries. Indian Journal of Extension Education. 1988; 24:71-73. 